\title{
From Dualism to Monism: The Structure of Revolution in Kenya's Constitutional Treaty Practice
}

\author{
Makumi Mwagiru
}

\section{Introduction}

The constitutional referendum in Kenya on 4 August 2010 in which the citizens overwhelmingly approved the new constitution was a hallmark event in more than one aspect. It paved the way for the promulgation of Kenya's second constitution. The new constitution has reconfigured Kenya's institutions across board. It also created a scientific revolution in Kenya's treaty practice. For the first time, Kenya's treaty practice is enshrined constitutionally and marks a shift from the old dualist practice to monism. This article examines the character and structure of that scientific constitutional revolution.

In the face of all the fundamental changes that the new constitution has made in Kenya's political life, it would be easy to overlook those in Kenya's treaty practice, or even underestimate their importance. It would also be easy to overlook their significance for Kenya's domestic legal relations, and its external diplomatic and legal relations.

Treaties - bilateral and multilateral - are one of the clearest manifestations of the complex interdependence of international relations. States enter into agreements either bilaterally or multilaterally, on a wide range of issues touching on their mutual relations. So pervasive is the system of agreements and treaties in the system that if the world map was marked to show the treaties and agreements existing in the international system, the map would disappear, as would the traditional territorial borders reflected on maps. In the face of this reality, it is clear that without the system of treaties and agreements pervading international relations, the world would be more impoverished. Treaties are an increasingly important feature of international and regional relations. They are an important aspect of diplomacy, and a notable feature of regional diplomacy.

The existing treaty regime covers all the spatial domains of international law and relations. This is an important feature of treaties, which prescribe rules in all the domains of international relations. These spatial domains range from outer space about which there is an important set of treaties beginning with the Outer Space Treaty; the sea and the deep seabed which are regulated by the UN Convention on the Law of the Sea; airspace which is regulated by both multilateral treaties beginning with Chicago Convention (1944) to a complex system of bilateral air services agreements; and to the environment where there is now a set of treaties regulating different aspects of international environmental relations. Apart from the physical ones, treaties occupy other spaces too. They regulate other relations between states: from political relations such as diplomacy and consular relations; to territorial relations including the definition of territories, and statehood; and beyond cooperative relations (i.e. the law of peace in international law). Treaties also govern relations during conflict, as humanitarian international law as in the 1949 Geneva Conventions and their two additional protocols of 1977. The international law regime further goes beyond these and concerns itself with creations of the human mind, aspects of which are regulated through a distinct treaty 
regime. Thus inventions and patents, and trade marks the creation of books and poetry and music are all under-girded by the system of international law in its treaty domain. The system of human rights is another domain which is under-girded and promoted by the international treaty regime. It is probably the most important treaty regime given the repercussions of not obeying human rights such as holocausts and genocide. But it is also the one international treaty regime that governments have tried their best not to be bound by.

\section{The Domain of Treaty Practice}

Treaty practices of individual states define how those states will relate not only to international law generally, but with those treaties they have accepted to be bound by i.e. those treaties that the states have ratified. Treaty practice also establishes the political philosophy which governs the relationship between international and domestic law. But treaty practice also signifies the legal philosophy (i.e. the jurisprudence) that will govern the relationship between international law and municipal law. Treaty practice also specifies the relationship among the different branches of government, at least to the extent of the country's relationship with treaties. In particular it prescribes the role of each of the branches of government in the treaty domain, from its negotiation, ratification, and its interpretation. Treaty practice is often spelt out in the constitution of the country. All states have a treaty practice, although there are states that while having some kind of treaty practice have not enshrined it in their constitution. All states have a treaty practice because all states must in some way or the other interact with some of the thousands of treaties in the international system. The only difference between states in this respect is whether their treaty practice is ad hoc, or whether they have structured it in the form of a constitutional law. This is why the revolution in Kenya's treaty practice as enshrined in the new constitution is such an important moment in Kenya's diplomatic and political life.

Treaty practice is concerned with how, domestically, international law and municipal law relate to each other (Brownlie, 1990). Treaty practice is one part of the more general problem of how international law and municipal law interact with each other, and what their relationship should be. The other part of this problem is the status of customary international law in municipal law. The relationship between customary international law and municipal law has long been settled. It has been acknowledged that customary international law is part of municipal law, and is binding on all states. There is the outstanding problem that one part of international law is binding on states, while the other half is not immediately binding, and needs some specific action of states - in their treaty practice - to make treaties which a state has ratified binding municipally.

International law recognizes three doctrines that deal with the relationship between international and municipal law. The first is the monist school, which maintains that international law and municipal law are part of one overarching legal system. Since they are part of the same legal system, and because there is no competing relationship between them, treaties that a state has ratified are automatically part of municipal law, and are binding in that domain. Monist thinking maintains that municipal law must be consistent with international law; that both municipal law and international law must respect the values of the overarching legal system which is founded on natural law; and 
that as Lauterpacht has argued, international law and municipal law are ultimately concerned with the welfare of the individual. The second perspective is dualism, advocated by legal positivists. It argues that the two systems of law (international and municipal) are different systems of law, each competent in its own domain. From the dualist perspective, because of their differences, states apply municipal law with no obligation to make it conform to international law. In dualism, international law is binding municipally if the state automatically allows it to do so. The third perspective, argued by Fitzmaurice maintains that municipal law and international law operate in distinct fields; each is supreme in its own field, and there is no common field between them (Fitzmaurice, 1957). Unlike dualists who argue that there can be conflict between the two systems, coordination theory maintains that the two can never come into conflict; and that the only issue is the inability of the state to act domestically as required by international law. When the state is unable to meet its international obligations municipal law does not thereby become invalid. But the state must do something about meeting its international obligations. Thus states choose whether they want to be monists, or dualists, or how they wish to coordinate the two systems of law.

The monist and dualist schools each have an arm that provides for how states will deal with treaties. The monist school contains the methodology of incorporation. In that perspective, treaties are automatically incorporated into municipal law, and hence are automatically binding. The dualist school is supported by the methodology of transformation. In that methodology, treaties do not become automatically binding on states unless they have first been transformed into municipal law. The methodology of transformation requires that the legislature which makes laws domestically, must first of all transform treaties into municipal law. The transformation of treaties into municipal law entails clothing them domestically, by making them part of the statutes of the country. Thus in Kenya for example, the Vienna Convention on Diplomatic Relations was transformed into the Privileges and Immunities Act (chapter 179 of the laws of Kenya), while the 1949 Geneva Conventions were transformed into the Geneva Conventions Act (chapter 198 of the laws of Kenya).

Given the increasing importance of the treaty regime both internationally and regionally, this state of affairs has posed fundamental problems for international law and diplomacy. One of the problems is that in Kenya the different perspectives of monism and dualism were overridden, with uncritical support being given to the dualist approach. At the same time the debates between their methodologies of incorporation and transformation were done away with, and uncritical support was lent to the doctrine of transformation. The perception has therefore been in vogue in countries like Kenya before August 2010, that international law, especially treaties, must first of all be transformed before they can be applied domestically.

\section{Framework for Analysis: Emerging Constitutional Gestalt Switches}

Kenya's new constitution approved by the referendum on 4 August 2010 and promulgated on 27 August 2010 entails a gestalt switch in many ways and in various aspects of public and political life in Kenya. Depending on one's school of thought, the provisions on treaty practice in the new constitution clarify the erstwhile treaty practice which was characterized by many anomalies and inconsistencies; or the provisions on 
treaty practice in the new constitution provide a fundamental shift in Kenya's treaty practice, by creating a new paradigm for treaty practice in Kenya. In the latter perspective, the new constitution has midwifed a scientific revolution in Kenya's treaty practice. This is the perspective of this paper.

Thomas Kuhn, in The Structure of Scientific Revolutions, argued that scientists normally operate within the context of 'normal science', where they are engaged in solving the important puzzles of the day. In doing so, scientists work within one paradigm, because in the natural sciences paradigms are incommensurable, meaning that only one paradigm exists at any one time. In Kuhn's view, where there exists only a single paradigm, it is not the paradigm that should be blamed when a puzzle is not solved but the scientists themselves. In the course of time, the paradigm begins to develop anomalies, and when it does so, it increasingly becomes unable to be used as a tool for puzzle solving. When the paradigm develops significant anomalies and is unable any longer to solve the important problems of the day in the discipline, it is overthrown in a scientific revolution. Once it is overthrown in this way, a new paradigm is adopted, and scientists continue working within that paradigm, until it too develops significant anomalies and in the scientific revolutionary process it too gets overthrown in favour of a new one.

Kuhn's thinking was directed towards the natural sciences. That notwithstanding the main elements of his theory have been adopted in social sciences (Banks, 1984). There are important differences between the approach to paradigms in the natural sciences and that in the social sciences. In the social sciences, paradigms are commensurable, because in those disciplines there are many paradigms competing at the same time within a discipline. Indeed, the growth of many disciplines such as international relations, international law and others, has been achieved because of competing paradigms trying to explain better the state of the discipline.

Kuhn's philosophy of scientific revolutions helps to explain the fate of the 1963 constitution of Kenya. Hence, in terms of the constitution itself, it can be argued a la Kuhn, that the old constitution of Kenya developed significant anomalies over time; and in doing so, it was unable to solve important problems of the day in Kenya. Consequently, because of these significant anomalies, the 1963 constitution was overthrown in a scientific revolution, and was replaced by the 2010 constitution. Thus the new constitution marks a process of scientific constitutional revolution.

At the same time, in the domain of the constitution and constitutional practices, there are paradigms competing for mastery not in Kuhn's original meaning, but in the way that his thought came to be understood in the social sciences. One such domain is treaty law which encapsulates treaty practices as specified in constitutions. In the treaty domain, paradigms have been commensurable, with the monist (and incorporation) and the dualist (and transformation) theories competing for mastery of Kenya's treaty practice. In that perspective, the dualist (and transformation) perspective was dominant and plied its trade of solving treaty practice puzzles of the day in Kenya for the last forty seven years. However, in the course of doing so, it developed significant anomalies, and was consequently overthrown by the 2010 constitution, which has prescribed a monist (and incorporation) perspective for Kenya's treaty practice. Hence the dualist paradigm of treaty practice, which had in Kenya developed significant anomalies such as giving life 
the doctrine of 'domestication' has now been overthrown in a scientific revolution and been replaced by the monist paradigm.

\section{The Dualist Anomalies}

The practice of dualism developed certain anomalies, both in its international jurisprudential context, but also in its application in Kenya. In the context of the jurisprudence of international law, its major failing is that it makes too large a distinction between the fate of international customary law and of treaty law domestically. Dualist practice means that there is no problem about customary international law being incorporated in municipal law; but that there is a problem with the doctrine of incorporation for treaties. In its application, dualism thus makes an uncomfortable split in international law, and prescribes different methods for their applicability in municipal law. This poses problems for international jurisprudence. It maintains unending conflicts between customary international law and treaty law. If for example a treaty codifying customary international law is created, dualists would have no problem implementing the customary international law contained in the treaty in municipal law through transformation. On the other hand, when the same customary law is presented as a treaty, dualists would have serious problems applying it domestically unless it is first transformed into municipal law. This is problematical and poses challenges to the unity of international law. It divides international law into two clear domains, each with separate systems of their domestic application. This is the kind of problem that the monist perspective cures by maintaining that both systems are part of one legal system, and that both are incorporated into municipal law. Hence, the monist doctrine is one of the unity of international law, whatever the provenance of its creation.

The dualist practice in Kenya since independence illustrates the anomalies that this doctrine has imported to the treaty practice of Kenya. Although the 1963 constitution did not specify the applicable treaty practice in Kenya, the resulting practice developed over time. The lack of constitutional engagement with Kenya's treaty practice led it to be practiced in an ad hoc way. This ad hoc treaty practice meant that it was not always possible to know, on the basis of existing treaty practice which treaties were binding on Kenya and those that were not. It also meant that there were treaties that were considered binding on Kenya just because they had been ratified, although according to dualist practice they were not first transformed. On the other hand, some treaties gained the force of law in Kenya because, following dualist practice, they were first transformed into Kenyan municipal law.

Kenya's practice of dualism reflects the tensions that have historically existed between the legislature and the executive. The practice reflected the philosophy of dualism that treaties must be transformed into municipal law before they could take effect in Kenya. But the practice of transformation was championed by the executive rather than the legislature in that treaties, or some of them, were first ratified before they were tabled in parliament for amendments to other laws to make them conform to the treaties Kenya had already ratified by authority of the executive. For example, the Vienna Convention on Diplomatic Relations was ratified by Kenya in 1965. It was not however until 1970, five years after Kenya ratified it, that the Privileges and Immunities Act was enacted giving force to aspects of that treaty in Kenyan municipal law. Another example is the 
Northern Transit Corridor Agreement which was ratified but necessitated amendments to municipal laws of Kenya like the Insurance (Motor Vehicles) Third Party Risks Act (cap. 405, laws of Kenya). Similarly, the Law of the Sea Convention necessitated amendments to municipal laws such as the Fisheries Act. (Mwagiru \& Hunja, 1990).

Kenya's treaty practice until August 2010, to the extent that it is decipherable can be summarized as follows. Firstly, parliamentary action is not required for permissive treaties, that is, those whose provisions are not inconsistent with any law in force in Kenya. On the other hand, treaties that require an act or omission not expressly authorized by any laws of Kenya require an act of parliament to give them that effect. Thirdly, where a treaty contains provisions which are not catered for by existing laws, a statute should be enacted by parliament to give effect to such a treaty. Clearly from this Kenyan perspective, the executive has been able to ratify treaties - i.e. expressing consent for Kenya to be bound by a treaty - and parliament's role has been to amend any other laws so as to make them conform to Kenya's treaty commitments. This has in effect been a practice that merged elements of dualism and monism, but with no consistency in practice. Kenya's treaty practice until 2010 was therefore a corrupted dualist one, in which parliament was not required to give permission for the executive to ratify treaties; but where the executive ratified treaties, monist fashion, the role of parliament was to make amendments to other laws of Kenya to make them conform to the treaty.

This competition between the two arms of government (executive and legislature) has been a hallmark of Kenya's treaty practice. In the treaty domain, the executive has been the dominant arm, and in this sense the new constitution's enactment of the monist doctrine has merely ratified this existing state of affairs. It is not surprising that the executive should have emerged the stronger. One of the issues that have prompted Kenya's political and constitutional crises has been a very powerful executive, identified as an imperial presidency. The operations of this imperial presidency in the treaty making domain in Kenya may have been the rationale for the emergence of the 'domestication' rhetoric in Kenya's treaty practice. In this context the rhetoric of 'domestication' can charitably be seen as an attempt to tame the excessive powers of the executive in Kenya's treaty domain.

\section{The Dynamics of 'Domestication' in Kenya's Treaty Practice}

This discourse has been accompanied by one of the most dangerous terminologies in trying to explain the relationship between treaties and municipal law. The language has come in vogue that treaties must first of all be 'domesticated' as a way of making them comply with municipal law, and thus being applicable in that domain. The language of 'domestication' implies that treaties have first to be subjected to a process of 'domestication' in which they would take on the characteristics of the domestic legal system. 'Domestication' ended up doing away with the methodology and doctrine of transformation as understood in international law. Transformation in international law prescribed merely a methodology by which a treaty would be clothed in the outward garb of municipal law. But it did not entail subjecting treaties to the vicissitudes of municipal politics. 'Domestication' also more or less did away with the doctrine of incorporation, since in the epistemology of 'domestication' a system of incorporation could not exist. The language of 'domestication' posed a further far reaching problem for international 
law. It meant that for international law to be applicable domestically, it had to first of all be treated in the same way as municipal law was treated in the political domain of the state. In the political domain of some states, the law is not treated with respect, and hence politicians feel that they can change it, and even discard it when it does not serve their purposes. Thus the case that was made for the 'domestication' of treaties was that they should be made first to succumb to political processes in the same way that municipal law does before they can apply.

This approach poses a danger for the integrity of international law. It makes the international legal system subject to the manipulations of politicians and interest groups in pursuit of their sectoral interests. It makes a mockery of the international negotiating frameworks, in which states negotiate rules of international law that must apply to all states equally without the attempt to 'domesticate' them. The practice also flies in the face of important emerging universal perspectives in international law, especially in international human rights law, that there are some issues about which a state is bound whether or not it has signed and ratified a treaty.

The plea for 'domestication' in this respect was that the universalism of international law had no space in the municipal context, and could be done away with through domestic frameworks. This explains the responses that have met the issuing of warrants for the international criminal court. The idea is that such warrants should not be issued because the Statute of the ICC has not been 'domesticated', meaning subjecting it to domestic political processes which often champion impunity. The new constitution of Kenya, by making Kenya a monist state through section 2(5) that provides that the general rules of international law shall form part of the law of Kenya; and especially through section 2(6) that provides that any treaty of convention ratified by Kenya shall form part of the law of Kenya effectively kills the dangerous doctrine of 'domestication'.

As argued earlier, the idea of 'domestication' was an attempt to subdue international (treaty) law by making its subservient to municipal laws and practices. But it can also be understood in a local political context. The meaning behind 'domestication' was that parliament should play a more prominent, even domineering role in the treaty practices of Kenya. It meant, in essence that parliament should take the leading role in the ratification process in the country. In that practice, the treaty making process would be stood on its head. Firstly, there was no contention that the executive retained the right to negotiate treaties on behalf of the country. But once the treaty was negotiated, the practice of domestication was to table it in parliament which would then subject it to the law making processes in Kenya, and convert the treaty into a statute of Kenya. Once the treaty was so converted, and approved, it would be applicable in Kenya, being one of the laws of Kenya. The ratification process, if it followed would thus be a mere formality, and more or less a diplomatic nicety expressed in formal terms. This dynamic of 'domestication' in effect suggested that a treaty could only be ratified once it had become a statute of Kenya. It also meant that once 'domesticated' there was no real need to ratify the treaty since it would already have the force of law in Kenya.

This was a dangerous doctrine. It would have led to the practice where the substance of international treaty law would be binding in Kenya, for Kenyans, but other states could not enforce that law against Kenya since it would have remained a strictly municipal law. It would also have meant that should the enforcement of the treaty provisions as municipal law became cumbersome, and threaten some political interests in 
the country, the statute could be removed in the normal operation of domestic politics in Kenya. The politics of domestication are therefore evident: they are the politics of wanting to have one's cake and eat it. This political aspect of domestication would subject treaty law to the Kenyan domestic climate. In it, politicians could claim to be abiding by the requirements of international treaty consensus to the extent that a treaty had been converted into a domestic statute. But whenever the burdens of implementation of those rules became too hot to bear, the statute containing those treaty rules could be done away with. And the domestic politicians would claim that they were adhering strictly to the rule of law.

The epistemology of domestication is even more worrying. It entails that international law should only exist in domestic form, but can also be ousted by changing that domestic form, thus rendering it inapplicable internationally. In this way, it would essentially remove the fundamental basis for negotiations in international law of good faith, by insisting that good faith does not have to be practiced internationally, and that it can be held hostage to the domestic vicissitudes of local politics. This epistemology would also pose a fatal challenge to the jurisprudence of international (particularly multilateral) negotiations. Multilateral negotiations are founded on the need to give life to the complex interdependence of the modern international system. But if international negotiations are not eventually founded on good faith, and if their outcome is to be lent domestic form without the supporting diplomatic elements specified in documents of diplomacy like instruments of ratification, then the country's participation in the international diplomatic processes of interdependence would be greatly, if not permanently injured.

The dynamics of domestication do not sit easily with the international law of dualism. In the proper practice of dualism, parliament has a certain role to play in the process of treaty making and implementation. In this role, parliament discusses a treaty that has been negotiated, and votes whether the executive should be allowed to ratify it or not. In this process, if parliament votes for the ratification of a treaty, then the executive ratifies it, and by so doing that treaty becomes binding on the country. It may, or may not be transformed into a domestic statute, depending on the treaty habits of the country in question. The argument here is that transformation of the treaty is effected by parliamentary discussion of it, and its voting decision to allow its ratification. Hence, once the voting decision is made, the treaty is ratified and becomes binding on the country from the date of its ratification. The choice to clothe it in the garb of a domestic statute is thus not of the essence since the taste of the treaty would be in the voting decision of parliament rather than in the clothes it consequently wears.

That the whole essence of 'domestication' is conceptualized in the context of domestic politics can be illustrated from recent experiences of Kenya. In Kenya, following the electoral violence after the elections of 2007, it was acknowledged that individuals who were responsible for that election violence and the deaths that accompanied it should no longer enjoy the impunity that they had enjoyed in the past. The fight against impunity for crimes against international law has been codified in the statute of the international criminal court. Kenya has ratified that statute. It has also passed a statute implementing the Rome statute, which requires states parties to "ensure that there are procedures available under their national law for all of the forms of cooperation..." However, because of the trend of domestic politics, and the status of 
those involved in the violence in Kenya, the thinking emerged that parliament should enact a local statute creating a tribunal to try those involved in the planning and commission of the crimes against humanity. In the debates that followed, there was a substantial group of politicians who supported the local tribunal. The thinking was that with such 'domestication' of the trial process, they would be able to escape from the rigours of international criminal law, and would even enjoy continued impunity. Parliament did not pass the bill on the local tribunal that was being championed. Many parliamentarians took the view that 'domesticating' the trial aspects would encourage non-compliance with international criminal law, and that it would do so on the basis of domestic political configurations.

\section{The Unending Debate: Monism, Dualism and Human Rights}

The debate between monism and dualism has been a characteristic of international law for many years. In the general field of international law, it has been argued that this debate is not very much of the essence. This view is informed by the belief that in the general field of international law the debate may not matter because eventually both of them lead to the implementation of international law. This is a good point, although given the issues discussed in this paper this conclusion may not be fully valid. For, if dualism in some of the ways it is practiced tries to domesticate international treaty law, then clearly following the dualist perspective may lead to the non-application of international treaty law domestically, or have it implemented in ways that are so diluted that it cannot be said to be properly implemented at all.

One of the major complaints of dualism is that if the monist approach was adopted, it would mean that states can apply laws municipally which were not passed by parliament. In other words there is the fear that the role of parliament of making laws would be taken over by the executive, at least as far as treaties go. For exponents of dualism, this would offend the whole doctrine of the separation of powers, and would hence not bode well for the democratic tradition. This criticism can be answered by the argument that the adoption of the monist doctrine does not necessarily oust the role of parliament in law making. The reason why the role of parliament in law making would not thereby be overthrown is that, even in the monist treaty practice, parliament would still have the primary role of scrutinizing the treaties before it votes on whether to allow the executive to ratify them. Indeed, in this perspective, the role of parliament would actually be consolidated. The only thing that would be removed from this role is the ability to look at treaties from purely the domestic political perspective of political and sectoral interests. Hence, it can be concluded that the much talked about diminishing of parliament in the treaty making role is much overstated.

The adoption of the monist perspective to treaty making is especially useful in the human rights domain. As Judge Tanaka observed in taking a natural law perspective in the South West African Cases, human rights are the same and apply equally in international law and in municipal law. The growth of human rights treaties over the last fifty years or so underlines the importance that human rights and treaties about them have taken on. In the development of international human rights law - through many treaties the idea has come to be championed that human rights have increasingly become universal This universality of human rights has developed from the older territorial 
understanding, to the international framework, until currently to the universalist perspective. In the universalist perspective of human rights, it is understood that some human rights treaties, especially those promoting and protecting fundamental human rights are applicable to states whether or not they have ratified them. In this case, for the implementation of human rights treaties the doctrine of dualism would not be particularly useful, since the question of their ratification would not arise. Hence in the human rights domain, the only doctrine that makes sense is the monist one, through which such treaties are immediately incorporated into municipal law.

The monist approach to human rights treaties is supported by even more serious arguments of the jurisprudence of international law. In international law, originally only states were subjects of international law. This was later followed after the creation of the United Nations by the acceptance, ratified by the international court of justice, that international organizations, which are organizations made up of states, are also subjects of international law (Bowett, 1982). Until then, individuals were still considered to be objects rather than subjects of international law. The growth of human rights, beginning with the laws of war, and later extending to other domains of human rights pushed the idea that individuals are also to some extent subjects of international law. While there have been debates raging about the extent of individuals as subjects of international law, there is no little or no debate that they are subjects of international law. Indeed it is also agreed that the fact that individuals have certain procedural limitations does not oust their status as subjects of international law.

This thinking has led to the belief that in fact, individuals are the true addressees of international law. While international law addresses states and gives them rights and duties, the state is a legal creation, and its duties and rights are implemented and enforced by individuals. In addressing states in the general rules of international law and in treaties, international law thus effectively addresses individuals. In any case the development of international human rights law has increasingly formulated treaties which address individuals directly and give them rights and duties as individuals, rather than as citizens of states. In this trend of thinking, a case can be made for adopting the monist perspective. This perspective directly incorporates treaties, including human rights treaties in municipal law. Once this happens, individual citizens can directly plead the provisions of human rights treaties even in court, without being disabled by the fact that those treaties have not yet been transformed into municipal law. This means in a practical sense that in the monist era there will be an added challenge to judges, who now must command international rather than merely municipal law. For, if individual citizens can go to court on the basis that they have clear rights and duties specified by treaties - and maybe not by statute - then clearly judges adjudicating on those rights must do so on the basis of international law and be competent in international treaty law, especially its approaches to interpretation.

\section{The Diplomacy of Monist Treaty Practice in Kenya}

There are thus clear and undisputed grounds for the adoption of the monist approach to treaty practice in Kenya. As this article has argued the dualist practice that has been in operation in Kenya over the last almost five decades has, in the course of time developed significant anomalies. Those anomalies have meant that dualist practice has not been able 
to solve many important (treaty) problems of the day. In the perspective championed by Kuhn, when a paradigm develops significant anomalies in this way, it is overthrown in a scientific revolution, after which a new paradigm takes it place and goes along with the business of solving important puzzles of the day. The new constitution of Kenya in 2010 has signified the scientific revolution and overthrow of the dualist paradigm, and established the monist paradigm as the new problem solving one in the treaty practices of Kenya.

The adoption of monist treaty practice will indeed sharpen the separation of powers in Kenya. In this approach, the role of each of the three powers in Kenya will become even better defined. The executive will negotiate treaties; parliament will debate about them, and make voting decisions about whether they should be ratified. And following that decision making, and only following it, the executive will ratify the treaties as it is required to do by the laws and practices of treaty law and diplomacy. This will without doubt enhance significantly the diplomacy of treaty practice in Kenya. Since the constitution recognizes a ratified treaty as being part of the laws of Kenya, the old framework of transformation, or its various devices such as 'domestication' will no longer be a required treaty practice of the republic. Once the treaties have become law in this way, the courts will interpret them as is their judicial function.

The role of the courts will not just be limited to interpreting the treaties in a national decision making framework. In their role as interpreters of treaties, the courts are set to contribute significantly to the development of international jurisprudence, and especially international human rights law. This is why, given the monist framework that has now been put in the books in Kenya, judges will require to be well trained in international law if they are to discharge this constitutional duty properly.

In order to implement this new constitutional treaty practice for Kenya, it will be necessary to have a separate statute on Kenya's treaty practice. Such a statute will help to harmonise the treaty practice and all its various elements. It will spell out clearly the role of each of the three powers of state - the executive, parliament and the courts, in such a way that problems and contentions between them will be duly minimized, if not abolished altogether. In reducing the separation of powers conflicts, that statute will have enhanced the process of treaty making and its practices in Kenya.

\section{Conclusions}

This article has surveyed the implications of the new treaty practice of Kenya that was established by the 2010 constitution. It has examined the treaty practices that have endured in Kenya since independence, and pointed out some of the problems that it has spawned. In particular, it has been argued that the dualist perspective that has been in force in Kenya has encouraged the politicization of the treaty making process in the country. It has been noted that the treaty practice that has been practiced since independence has been held hostage by the reality that the other two arms of government have been overshadowed by the executive in the treaty making process. This overpowering by an imperial executive in turn generated rationales such as the domestication of treaties, as the basis on which treaties can be applied in municipal law. The doctrine of domestication has certain effects - jurisprudential, philosophical, and 
political - and it is these that have rendered the erstwhile treaty practice ineffective as a means of solving pressing treaty puzzles of the day in Kenya.

The thrust of the arguments made in this article is that dualist treaty practice developed significant anomalies over time, and has hence consequently rendered it unable - even unwilling - to solve the important treaty and international law problems of the day. In consequence, the dualist paradigm has now eventually been overthrown in a scientific constitutional revolution. This scientific revolution was long overdue in Kenya's treaty practice. It however raises the interesting problem of the fate of the overthrown treaty practice paradigm in Kenya. While some, like Kuhn have argued that an overthrown paradigm should stay that way and remain inoperational, others have made the more interesting point that even an overthrown paradigm should not be discarded because in the future, it may regenerate and help to solve future problems of the day. This is as it should be. In the international relations, international legal and diplomatic environment, and in the domestic one, which are all volatile, tools that might be engaged in future problem solving should be shelved but not discarded, because after all, they may yet live and fight another day.

\section{References}

Banks, Michael (1984) The Evolution of International Relations Theory. In Michael Banks (ed) Conflict in World Society: A New Perspective in International Relations. Brighton: Wheatsheaf Books 3-21

Bowett, D.W. (1982) The Law of International Institutions. London: Stevens \& Sons. Brownlie, Ian (1990) Principles of Public International Law. Oxford: Oxford University Press.

Fitzmaurice, G. (1957) The General Principles of International Law Considered from the Standpoint of the Rule of Law. 92 Hague Recueil, 68-94.

Kuhn, Thomas (1966) The Structure of Scientific Revolutions. Chicago: Chicago University Press.

Mwagiru, M \& Hunja, R. (1990) Some Aspects of Treaty Practice in Kenya. Lesotho Law Journal, 6.2:7-22. 